\title{
Synthesis and characterization of Polyindole and its catalytic performance study as a heterogeneous catalyst
}

\author{
PRAKASH CHHATTISE ${ }^{\mathrm{a}, \mathrm{b}}$, KALPANA HANDORE $^{\mathrm{a}}$, AMIT HORNE $^{\mathrm{a}}$, \\ KAKASAHEB MOHITE $^{b}$, ATUL CHASKAR $^{c}$, SABRINA DALLAVALLE $^{d}$ \\ and VASANT CHABUKSWAR ${ }^{\mathrm{a}, *}$ \\ ${ }^{a}$ Department of Chemistry, Nowrosjee Wadia College, University of Pune, 19, Joag Path, Pune 411001 , India \\ ${ }^{b}$ Department of Chemistry, Haribhai V Desai College, Pune 411 002, India \\ ${ }^{c}$ National Centre for Nanosciences and Nanotechnology, Mumbai University, Mumbai, India \\ ${ }^{\mathrm{d}}$ Department of Food, Environmental and Nutritional Sciences, Università degli Studi di Milano, Milan, Italy \\ e-mail:vvchabukswar@gmail.com
}

MS received 19 October 2015; revised 18 December 2015; accepted 6 January 2016

\begin{abstract}
The catalytic performance study of polyindole as a heterogeneous catalyst is reported for the synthesis of 3,3'-arylmethylene-bis- $1 H$-Indole derivatives using various substituted aldehydes and indole under reflux reaction condition with good to excellent yield. Polyindole was synthesized by chemical oxidative polymerization using citric acid as a dopant. The synthesized polymer was well characterized by various spectroscopic techniques like FT-IR, XRD, FESEM, etc. The XRD pattern confirms the partially crystalline nature of polyindole. The FESEM images of polyindole revealed the formation of irregularly shaped particulate nature with size in the range of 0.2 to 6 micron. In FT-IR spectrum, the major peak at $\sim 3400 \mathrm{~cm}^{-1}$ indicates N$\mathrm{H}$ stretching and at $1564-1624 \mathrm{~cm}^{-1}$ indicates C-C stretching of benzenoid ring of indole. The presence of peak at $\sim 3400 \mathrm{~cm}^{-1}$ indicates that the polymerization does not occur at nitrogen. The present protocol has certain advantages like recyclability, low loading of the catalyst, low-cost and efficient use of polyindole as a heterogeneous catalyst.
\end{abstract}

Keywords. Polymerization; polyindole; arylmethylene bis- $1 H$-Indole; heterogeneous catalyst; recyclability.

\section{Introduction}

As a part of recent investigations in the field of polymers, conducting polymers like polyaniline and its analogues have received significant attention as catalysts for diverse organic reactions and transformations. 3,3'arylmethylene bis- $1 H$-Indole and its derivatives are well known and an important class of heterocyclic compounds which are used in pharmaceuticals as bioactive intermediates, agrochemicals and in material science. ${ }^{1}$ They exhibit a broad spectrum of biological activities such as antimicrobial and antifungal, ${ }^{2}$ antibacterial, ${ }^{3}$ antitumor, ${ }^{4}$ and antioxidantetc agents. ${ }^{5}$ Recently, bis (5-methoxy-3-indolyl) methanes have been used as DNA-based electrochemical biosensors that considerably reduce the growth of cancer cell lines such as HOP-92 (lung), A498 (renal), and MDAMB-231/ITCC (breast). ${ }^{6}$ The condensation of aldehydes with indole is an important reaction in organic chemistry to afford 3,3'-arylmethylene bis-1H Indole. Various

\footnotetext{
*For correspondence
}

methods have been studied to effect the condensation reaction of indole with a variety of aldehydes in the literature. Most of the reported methods have employed conventional Lewis acids as well as protic acids as catalysts. Perumal et al., synthesized bisindolyl alkanes using $\mathrm{InCl}_{3}$ as Lewis acid catalyst. ${ }^{7}$ An excess amount of Lewis acid is needed for the synthesis of heterocyclic compounds as it can be destroyed by the nitrogen atom of heterocyclic compounds. Mishra et al., reported synthesis of 3, 3'-arylmethylene bis- $1 \mathrm{H}$ Indole with $\mathrm{ZrOCl}_{2} \cdot 8 \mathrm{H}_{2} \mathrm{O}$ which required prolonged reaction time, $\sim 10$ to $16 \mathrm{~h}^{8}{ }^{8}$ Kurosh and Masoumeh Sharifi-Kiasaraaie synthesised bisindolyl alkanes using [BMIM]BF ${ }_{4}$ as ionic liquid within 3-4 h with low yield of the corresponding product. ${ }^{9}$ Various other catalysts used are $\mathrm{ZrOCl}_{2} \cdot 8 \mathrm{H}_{2} \mathrm{O}$ / silica gel, ${ }^{10}$ silica supported $\mathrm{NaHSO}_{4} /$ amberlyst- $15,{ }^{11} \mathrm{FeCl}_{3} /$ ionic liquid, ${ }^{12}$ lithium perchlorate, ${ }^{13} \mathrm{Cu}\left(\mathrm{BF}_{4}\right) \cdot \mathrm{SiO}_{2},{ }^{14}$ Ionic liquid, ${ }^{15} \mathrm{KHSO}_{4},{ }^{16} \mathrm{In}(\mathrm{OTf})_{3},{ }^{17} \mathrm{Dy}(\mathrm{OTf})_{3},{ }^{18} \mathrm{I}_{2},{ }^{19} \mathrm{NBS},{ }^{19}$ $\mathrm{H}-\mathrm{Y}$ zeolite, ${ }^{20}$ Ion exchange resin, ${ }^{21} \mathrm{H}_{3} \mathrm{PMo}_{12} \mathrm{O}_{40} \times \mathrm{xH}_{2} \mathrm{O},{ }^{22}$ Montmorillonite $\mathrm{K} 10,{ }^{23} \mathrm{Sb}_{2}\left(\mathrm{SO}_{4}\right)_{3},{ }^{24} \mathrm{Ln}(\mathrm{OTf})_{3},{ }^{10}$ and clay. ${ }^{24}$

Most of the reported methods suffer from various disadvantages such as prolonged reaction time, harsh reaction conditions, use of expensive Lewis acids, 
toxic metal ions and tedious work-up procedures. In search of better catalytic systems, herein we have studied polymer-supported reagents for the synthesis of 3 , 3 '-arylmethylene bis- $1 H$ Indole. Polyindole plays an important role in organic synthesis enabling chemists to prepare various organic compounds efficiently, removing excess reagents and byproducts by simple filtration and simplifying work-up procedure and purification. The present study demonstrates the synthesis of polyindole by oxidative chemical polymerization and its effective use as a heterogeneous catalyst for the synthesis of 3, 3'-arylmethylene bis- $1 H$ Indole avoiding use of expensive and toxic reagents or solvents (scheme 1).

\section{Experimental}

\subsection{Materials and methods}

All the chemicals and solvents (Aldrich, Fluka, and Merck) were of analytical grade and were used as received without further purification.

\subsection{Synthesis of Polyindole}

For the synthesis of polyindole, $10 \mathrm{mmol}$ of indole monomer and $10 \mathrm{~mL}$ of methanol were mixed in a round bottom flask under nitrogen atmosphere with constant stirring. The nitrogen purging was continued for $1 \mathrm{~h}$ followed by addition of $10 \mathrm{mmol}$ citric acid. To the above reaction mixture, Copper chloride solution (10 mmol) was added dropwise under constant stirring at low temperature $\left(0-5^{\circ} \mathrm{C}\right)$. The reaction mixture was sonicated for $1 \mathrm{~h}$. the greenish black precipitate of the polymer was isolated by filtration and washed with distilled water until the supernatant liquid became colourless. Copper chloride and citric acid are water soluble and hence easily washed away. Finally, the polymer material was dried under vacuum at $50-60^{\circ} \mathrm{C}$ in an oven. The obtained polyindole was characterised by various spectral techniques such as FT-IR, XRD and SEM.

\subsection{Characterization}

X-ray diffraction (XRD) analysis of the synthesized polyindole was carried out using BrukerAXS model D$8,\left(10\right.$ to $70^{\circ}$ range, scan rate $\left.=1^{\circ} \mathrm{min}^{-1}\right)$ equipped with a monochromator and $\mathrm{Ni}$-filtered $\mathrm{Cu} \mathrm{K} \alpha$ radiation $(\lambda=$ $1.542 \AA)$. For this purpose, the polymer sample was dispersed in ethanol and a small droplet was applied on the aluminium sheet. The prepared sample was sputtered with $\mathrm{Au}$ and used for FESEM analysis. FTIR analysis was carried out using Shimadzu A 800 equipped with diffuse reflectance mode.

\subsection{General procedure for the synthesis of 3, 3'-arylmethylene bis-1H Indole}

In a $25 \mathrm{~mL}$ round bottom flask, mixture of indole $(2.0$ $\mathrm{mmol})$, aldehyde $(1.0 \mathrm{mmol})$ and polyindole $(5 \mathrm{wt} \%)$ with respect to aldehydes in acetonitrile $(5 \mathrm{~mL})$ was refluxed with constant stirring for 1 to $2 \mathrm{~h}$. The progress of the reaction was monitored by thin layer chromatography TLC (n-hexane/ethyl acetate 30\%), on Merck's silica gel plates $\left(60 \mathrm{~F}_{254}\right)$. After completion of the reaction, the catalyst was filtered and the resulting crude product was extracted with ethyl acetate. All the products were purified by using neutral silica gel (60-120 mesh) and column chromatography using hexane and ethyl acetate as eluents. ${ }^{1} \mathrm{H}$ and ${ }^{13} \mathrm{C}$-NMR spectra were recorded in $\mathrm{CDCl}_{3}$ and DMSO- $\mathrm{d}_{6}$ as the solvent on Varian $400 \mathrm{MHz}$ NMR spectrometer. Proton chemical shifts $(\delta)$ were recorded relative to TMS $(\delta=0)$ as internal standard and expressed in ppm. Coupling constants $(J)$ are given in Hertz. IR spectra were recorded on a Shimadzu A 800R in the range of $400-4000 \mathrm{~cm}^{-1}$. Melting points were determined on Buchi M-560.

\subsection{Characterization data}

2.5a 3, 3'- (phenylylmethylene)bis- 1H-Indole (table 3 entry 1): ${ }^{1} \mathrm{H}$ NMR (DMSO- $\mathrm{d}_{6}, 400 \mathrm{MHz}, \mathrm{Me}_{4} \mathrm{Si}$ ): $\delta 5.8$ $(1 \mathrm{H}, \mathrm{CH}), 6.7\left(2 \mathrm{H}, J_{\mathrm{HH}}=2 \mathrm{~Hz}, \underline{\mathrm{C}}_{2}\right), 6.86\left(2 \mathrm{H}, J_{\mathrm{HH}}=\right.$ 7.6 and $\left.14.6 \mathrm{~Hz}, \underline{\mathrm{CH}}_{2}\right), 7.1\left(2 \mathrm{H}, J_{\mathrm{HH}}=8\right.$ and $14.80 \mathrm{~Hz}$,

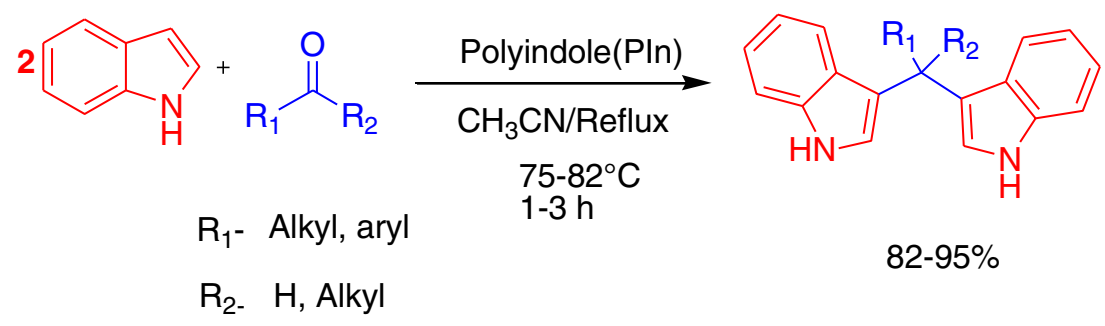

Scheme 1. Synthesis of 3, 3'-arylmethylene bis-1H Indole. 


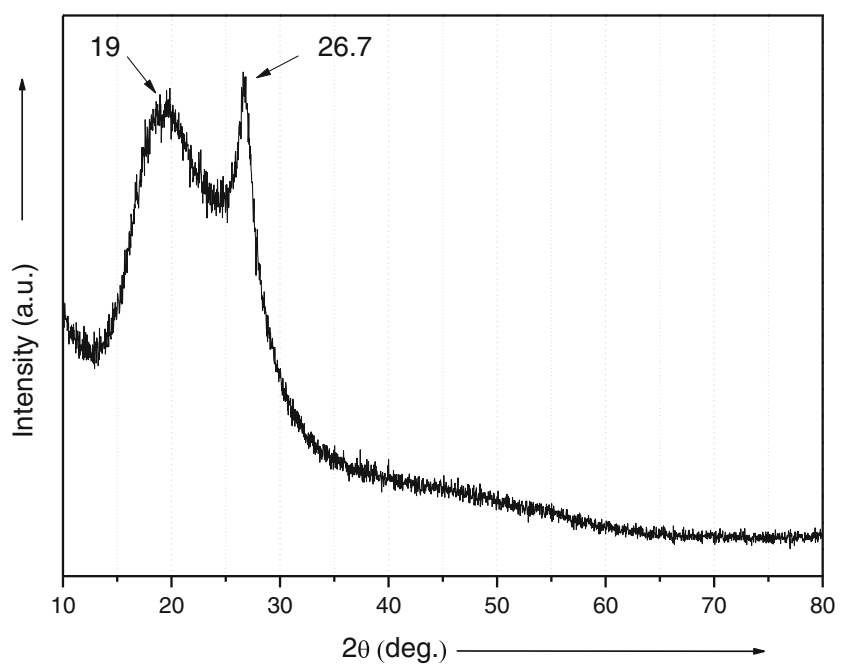

Figure 1. XRD of polyindole.

$\left.\mathrm{C}_{2}\right), 7.02\left(1 \mathrm{H}, J_{\mathrm{HH}}=7.2\right.$ and $\left.14.40 \mathrm{MHz}, \mathrm{Ph}\right), 7.4(4 \mathrm{H}$, $J_{\mathrm{HH}}=8$ and $\left.16 \mathrm{~Hz}, \mathrm{Ph}\right), 7.2(4 \mathrm{H}), 10.8(2 \mathrm{H}, \mathrm{br}, \mathrm{NH})$; ${ }^{13} \mathrm{C} \mathrm{NMR}\left(\mathrm{CDCl}_{3}, 200 \mathrm{MHz},\right): \delta 144.8,136.4,128.19$, $127.9,126.54,125.64,123.41,120.74,118.98,118.03$, 117.97, 111.32; M.p. $124-126^{\circ} \mathrm{C} ; \mathrm{m} / \mathrm{z} 321.38$

$2.5 \mathrm{~b}$ 3, 3'- ((4-methoxyphenyl) methylene) bis-1H Indole (table 3, entry 4$):{ }^{1} \mathrm{H} \mathrm{NMR}\left(\mathrm{CDCl}_{3}, 400 \mathrm{MHz}\right.$, $\left.\mathrm{Me}_{4} \mathrm{Si}\right): \delta 3.7(3 \mathrm{H}, 3 \mathrm{OMe}), 5.8(1 \mathrm{H}, \mathrm{CH}), 6.6(2 \mathrm{H}, \mathrm{Ph})$, $6.8\left(2 \mathrm{H}, \mathrm{dd}, J_{\mathrm{HH}}=4.80 \mathrm{~Hz}, \mathrm{Ph}\right), 7.0(2 \mathrm{H}, \mathrm{Ph}), 7.14$ $\left(2 \mathrm{H}, J_{\mathrm{HH}}=7.2\right.$ and $\left.14.4 \mathrm{~Hz}, \mathrm{Ph}\right), 7.25(2 \mathrm{H}, \mathrm{m}, \mathrm{Ph})$, $7.37\left(3 \mathrm{H}, \mathrm{dd}, J_{\mathrm{HH}}=12.0 \mathrm{~Hz}, \mathrm{Ph}\right), 7.8(2 \mathrm{H}, \mathrm{bs}, \mathrm{NH})$; M.p. $186-188^{\circ} \mathrm{C} ; \mathrm{m} / \mathrm{z} 351.25$.

$2.5 \mathrm{c} 3,3$ '- ((4-nitrophenyl) methylene) bis-1H Indole (table 3, entry 6): ${ }^{1} \mathrm{H}$ NMR (DMSO- $\mathrm{d}_{6}, 400$ $\left.\mathrm{MHz}, \mathrm{Me}_{4} \mathrm{Si}\right): \delta 6(1 \mathrm{H}, \mathrm{CH}), 6.8\left(2 \mathrm{H}, J_{\mathrm{HH}}=8.4\right.$, $\mathrm{CH}), 6.7(2 \mathrm{H}, \mathrm{d}), 6.84\left(2 \mathrm{H}, J_{\mathrm{HH}}=8.0\right.$ and $15.2 \mathrm{~Hz}$, $\mathrm{Ph}), 7.01\left(2 \mathrm{H}, J_{\mathrm{HH}}=7.60\right.$ and $\left.14.8 \mathrm{~Hz}, \mathrm{Ph}\right), 7.1(2 \mathrm{H}$,
$\left.J_{\mathrm{HH}}=8.4 \mathrm{~Hz}, \mathrm{Ph}\right), 7.2\left(2 \mathrm{H}, J_{\mathrm{HH}}=8.0 \mathrm{~Hz}, \mathrm{Ph}\right), 7.3(2 \mathrm{H}$, $\left.J_{\mathrm{HH}}=8.4 \mathrm{~Hz}, \mathrm{Ph}\right), 10.8$ (1H, bs, NH); M.p. $222-224^{\circ} \mathrm{C}$.

2.5d 3, 3'- ((3,4dimethoxyphenyl) methylene) bis- $1 \mathrm{H}$ -Indole (table 3, entry 7): ${ }^{1} \mathrm{H} \mathrm{NMR}\left(\mathrm{CDCl}_{3}, 400 \mathrm{MHz}\right.$, $\left.\mathrm{Me}_{4} \mathrm{Si}\right): \delta 3.7(3 \mathrm{H}, \mathrm{OMe}), 3.8(3 \mathrm{H}, \mathrm{OMe}), 5.8(1 \mathrm{H}, \mathrm{CH})$, $6.6(2 \mathrm{H}, \mathrm{Ph}), 6.77\left(1 \mathrm{H}, J_{\mathrm{HH}}=8.4 \mathrm{~Hz}, \mathrm{Ph}\right), 6.83(1 \mathrm{H}$, $\mathrm{Ph}), 6.9(1 \mathrm{H}, \mathrm{Ph}), 7.0\left(2 \mathrm{H}, J_{\mathrm{HH}}=7.6\right.$ and $\left.16 \mathrm{~Hz}, \mathrm{Ph}\right)$, $7.1\left(2 \mathrm{H}, J_{\mathrm{HH}}=8.0\right.$ and $\left.14.8 \mathrm{~Hz}, \mathrm{Ph}\right), 7.3\left(4 \mathrm{H}, \mathrm{dd}, J_{\mathrm{HH}}=\right.$ $8.0 \mathrm{~Hz}, \mathrm{Ph}), 7.9(2 \mathrm{H}, \mathrm{bs}, \mathrm{Ph}) ;{ }^{13} \mathrm{C} \mathrm{NMR}\left(\mathrm{CDCl}_{3}, 200\right.$ $\mathrm{MHz}$,) $\delta$ 40.0, 50.6, 110.9, 111.0, 112.2, 119.1, 119.8, $119.9,120.5,121.8,123.5,127.0,136.7,147.2$, 148.6; M.p. $196-198^{\circ} \mathrm{C} ; \mathrm{m} / \mathrm{z} 379.54$.

2.5e 3, 3'-((4 N,Ndimethylphenyl) methylene) bis-1H -Indole (table 3, entry 8): ${ }^{1} \mathrm{H} \mathrm{NMR}\left(\mathrm{CDCl}_{3}, 400 \mathrm{MHz}\right.$, $\left.\mathrm{Me}_{4} \mathrm{Si}\right): \delta 2.9(6 \mathrm{H}, \mathrm{Nme} 2), 5.8(1 \mathrm{H}, \mathrm{CH}), 6.67(4 \mathrm{H}, \mathrm{Ph})$, $6.9(2 \mathrm{H}, \mathrm{m}, \mathrm{Ph}), 7.2-1.12(4 \mathrm{H}, \mathrm{m}, \mathrm{Ph}), 7.3\left(2 \mathrm{H}, J_{\mathrm{HH}}=\right.$ $8.4 \mathrm{~Hz}, \mathrm{Ph}), 7.4\left(2 \mathrm{H}, J_{\mathrm{HH}}=8.0, \mathrm{Ph}\right), 7.8(2 \mathrm{H}, \mathrm{bs}, \mathrm{NH})$; M.p. $206-208^{\circ} \mathrm{C} ; \mathrm{m} / \mathrm{z} 366$.

$2.5 \mathrm{f} 3$, 3'- ((4-Fluorophenyl) methylene) bis-1HIndole (table 3, entry 9): ${ }^{1} \mathrm{H}$ NMR $\left(\mathrm{CDCl}_{3}, 400\right.$ $\left.\mathrm{MHz}, \mathrm{Me}_{4} \mathrm{Si}\right): \delta 5.8(1 \mathrm{H}, \mathrm{CH}), 6.8(2 \mathrm{H}, \mathrm{Ph}), 6.93-7.02$ (4H,Ph), 7.1-7.2 (2H, m, Ph), 7.27-7.30 (3H,Ph), 7.4 $\left(4 \mathrm{H}, \mathrm{dd}, J_{\mathrm{HH}}=2\right.$ and $\left.7.60 \mathrm{~Hz}, \mathrm{Ph}\right), 7.8(2 \mathrm{H}, \mathrm{br}, \mathrm{NH})$; M.p. $82-84^{\circ} \mathrm{C}$; $\mathrm{m} / \mathrm{z} 338.8$

$2.5 \mathrm{~g} 3$, 3'- ((4-chlorophenyl) methylene) bis-1H Indole (table 3, entry 10): ${ }^{1} \mathrm{H}$ NMR (DMSO- $\mathrm{d}_{6} 400$ $\left.\mathrm{MHz}, \mathrm{Me}_{4} \mathrm{Si}\right): \delta 5.9(1 \mathrm{H}), 6.8(2 \mathrm{H}, \mathrm{br}), 7.4-7.80(12 \mathrm{H})$, 10. $2(2 \mathrm{H}$, bs, $\mathrm{NH})$; M.p. $74-76^{\circ} \mathrm{C}$.

2.5h 3, 3'-((3hydroxy,4-methoxyphenyl) methylene) bis-1H -Indole (table 3, entry 13): ${ }^{1} \mathrm{H} \mathrm{NMR}\left(\mathrm{CDCl}_{3}\right.$,
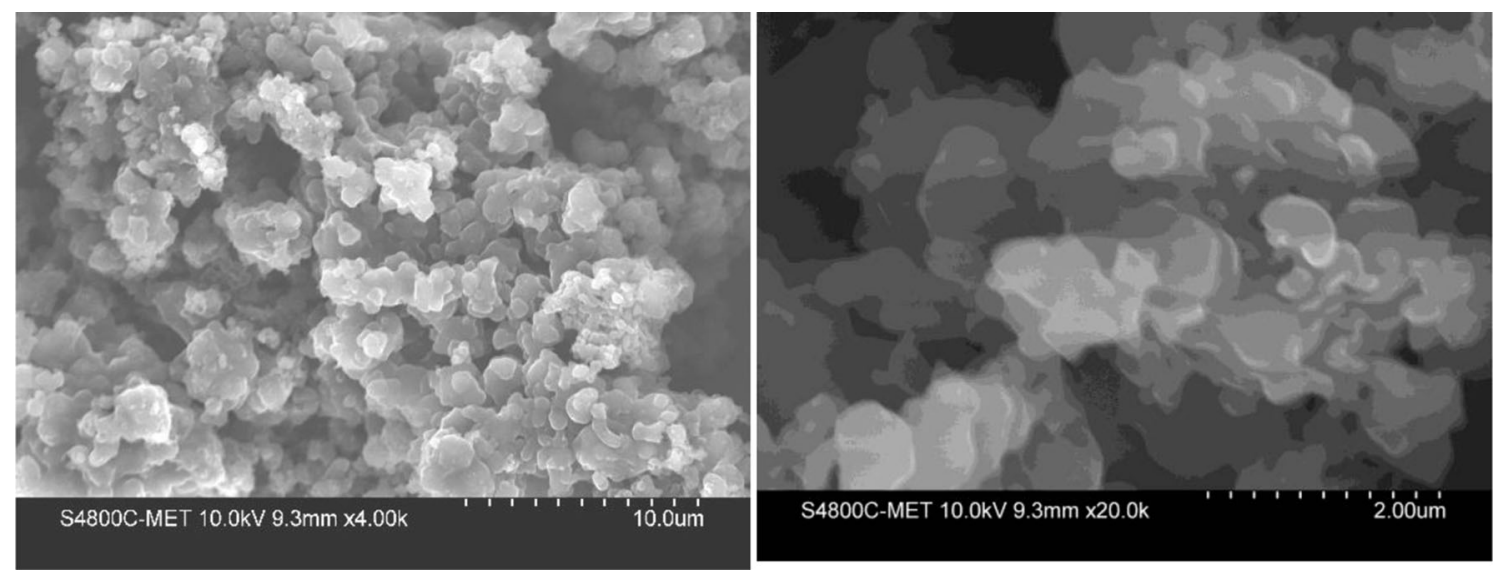

Figure 2. FE-SEM image of polyindole. 


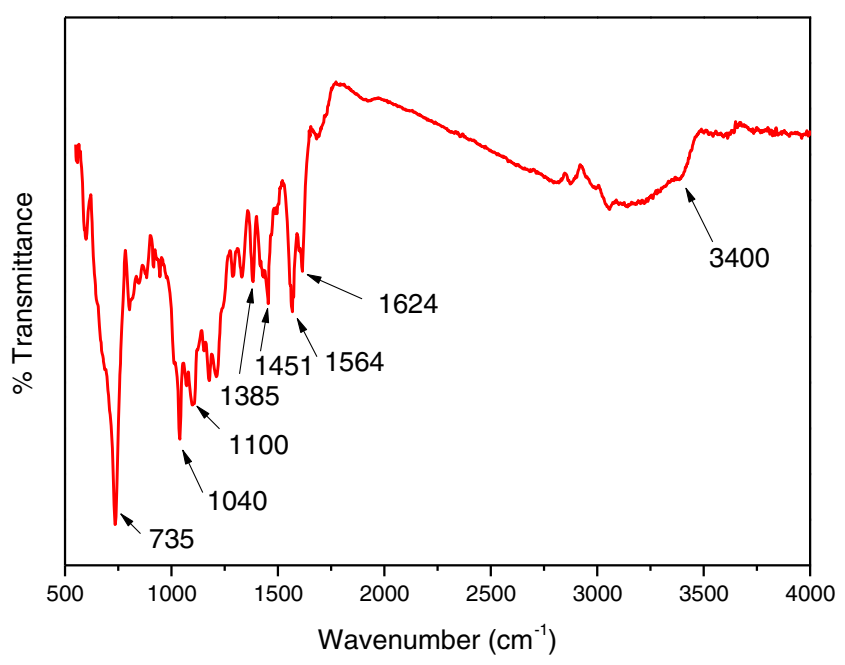

Figure 3. FTIR spectra of polyindole.

$\left.400 \mathrm{MHz}, \mathrm{Me}_{4} \mathrm{Si}\right): \delta 3.8(3 \mathrm{H}, \mathrm{OMe}), 5.5(1 \mathrm{H}, \mathrm{OH}), 5.8$ $(1 \mathrm{H}, \mathrm{CH}), 6.6(2 \mathrm{H}, \mathrm{Ph}), 6.7\left(1 \mathrm{H}, J_{\mathrm{HH}}=8.4 \mathrm{~Hz}, \mathrm{Ph}\right), 6.83$ $\left(1 \mathrm{H}, \mathrm{dd}, J_{\mathrm{HH}}=8.0 \mathrm{~Hz}, \mathrm{Ph}\right), 6.9(1 \mathrm{H}, \mathrm{s}), 7.0\left(2 \mathrm{H}, J_{\mathrm{HH}}=\right.$ 7.2 and $14.4 \mathrm{~Hz}, \mathrm{Ph}), 7.1\left(2 \mathrm{H}, J_{\mathrm{HH}}=7.6\right.$ and $15.2 \mathrm{~Hz}$, $\mathrm{Ph}), 7.3\left(2 \mathrm{H}, J_{\mathrm{HH}}=8.0 \mathrm{~Hz}, \mathrm{Ph}\right), 7.4\left(2 \mathrm{H}, J_{\mathrm{HH}}=8.0\right.$ $\mathrm{Hz}, \mathrm{Ph}), 7.8$ (2H, bs, NH); M.p. $110-111^{\circ} \mathrm{C} ; \mathrm{m} / \mathrm{z} 365.46$ (M-).

2.5i Tri (1-H-indol-3-yl) methane (table 3, entry 16): ${ }^{1} \mathrm{H}$ NMR (DMSO-d $\left.600 \mathrm{MHz}, \mathrm{Me}_{4} \mathrm{Si}\right) \delta 6.4(1 \mathrm{H}, \mathrm{CH})$, $6.6\left(2 \mathrm{H}, J_{\mathrm{HH}}=8.4, \mathrm{CH}\right), 6.7(2 \mathrm{H}) 6.84\left(2 \mathrm{H}, J_{\mathrm{HH}}=8.0\right.$ and $15.2 \mathrm{~Hz}, \mathrm{Ph}), 7.01\left(2 \mathrm{H}, J_{\mathrm{HH}}=7.60\right.$ and $14.8 \mathrm{~Hz}$, $\mathrm{Ph}), 7.1\left(2 \mathrm{H}, J_{\mathrm{HH}}=8.4 \mathrm{~Hz}, \mathrm{Ph}\right), 7.2\left(2 \mathrm{H}, J_{\mathrm{HH}}=8.0 \mathrm{~Hz}\right.$, $\mathrm{Ph}), 7.3\left(2 \mathrm{H}, J_{\mathrm{HH}}=8.4 \mathrm{~Hz}, \mathrm{Ph}\right), 9.1(1 \mathrm{H}, \mathrm{bs}, \mathrm{NH}), 10.7$ $(2 \mathrm{H}$, bs, $\mathrm{OH})$; M.p. $162-164^{\circ} \mathrm{C}$.

\section{Results and Discussion}

\subsection{XRD Analysis}

The synthesized polyindole was analysed by powder $\mathrm{X}$-ray diffractometry to identify the crystalline phases. XRD pattern of polyindole is depicted in figure 1 .

Table 1. Optimization of the amount of catalyst.

\begin{tabular}{lcc}
\hline Entry & PInd (x wt \%) & Yield \\
\hline 1 & 0.5 & $72 \%$ \\
2 & 1.0 & $83 \%$ \\
3 & 2.5 & $90 \%$ \\
4 & 5.0 & $95 \%$ \\
5 & 7.5 & $96 \%$ \\
6 & 10.0 & $96 \%$
\end{tabular}

Reaction Conditions: Aldehyde (1 mmol), Indole (0.117 g, $2 \mathrm{mmol}$ ), catalyst (x wt\%); stirred in $5 \mathrm{~mL}$ acetonitrile at reflux temperature, time $1.5 \mathrm{~h}$. Isolated yields.
It shows two reflection peaks, first one at $19^{\circ}$ is a broad peak and another sharp peak is at $26.7^{\circ}$. The broad peak confirms the polymerization of indole. Due to poor crystalline structure, polymeric materials usually show broad reflection peaks. Additionally, the sharp peak at $26.7^{\circ}$ validates partial crystalline nature of polyindole.

\subsection{FE-SEM Analysis}

The morphology and dimensions of polyindole were examined by FESEM and high and low resolution FESEM images are reproduced in figure 2. The synthesised polyindole reveals the formation of irregularly shaped particles with size ranging from 0.2 to 6 micron. The high resolution image depicts the presence of spherical particles with smooth surface which are fused together to form chunk like morphology.

\subsection{FT-IR Analysis}

The FT-IR spectrum of polyindole is shown in figure 3 . The major peak at $\sim 3400 \mathrm{~cm}^{-1}$ indicates $\mathrm{N}-\mathrm{H}$ stretching, peak at $1564-1624 \mathrm{~cm}^{-1}$ indicates C-C stretching of benzenoid ring of indole, peaks at $1451 \mathrm{~cm}^{-1}$ and 1385 $\mathrm{cm}^{-1}$ indicate $\mathrm{C}-\mathrm{N}$ and $\mathrm{C}=\mathrm{N}$ stretchings, respectively, and the peak at $735 \mathrm{~cm}^{-1}$ indicates out-of-plane deformation of benzene. The presence of peak at $\sim 3400$ $\mathrm{cm}^{-1}$ indicates that the polymerization does not occur at nitrogen.

\subsection{Synthesis of 3, 3'-arylmethylene bis-1H Indole using polyindole}

Initially, the optimization of the general reaction condition was carried out by the model reaction between p-nitrobenzaldehyde and indole using polyindole (PInd) as a catalyst. The aldehyde and indole in 1:2

Table 2. Effect of Solvent.

\begin{tabular}{lccc}
\hline Entry & Solvent & $\begin{array}{c}\text { Time } \\
(\mathrm{min})\end{array}$ & $\begin{array}{c}\text { Yield } \\
\%\end{array}$ \\
\hline 1 & Ethanol & 60 & 92 \\
2 & Acetonitrile & 90 & 95 \\
3 & DCM & 55 & 84 \\
4 & Chloroform & 45 & 80 \\
5 & Benzene & 60 & 70 \\
6 & THF & 55 & 82 \\
7 & DMF & 75 & 80 \\
8 & 1,4 dioxane & 60 & 78 \\
\hline
\end{tabular}

Reaction Conditions: Aldehyde (1 mmol), Indole $(0.117 \mathrm{~g}$, $2 \mathrm{mmol}$ ), catalyst (5 wt \%); stirred in $5 \mathrm{~mL}$ acetonitrile at reflux temperature, time $1.5 \mathrm{~h}$. Isolated Yields. 
Table 3. Polyindole catalyzed synthesis of 3, 3 'arylmethylene bis- $1 H$ indole.

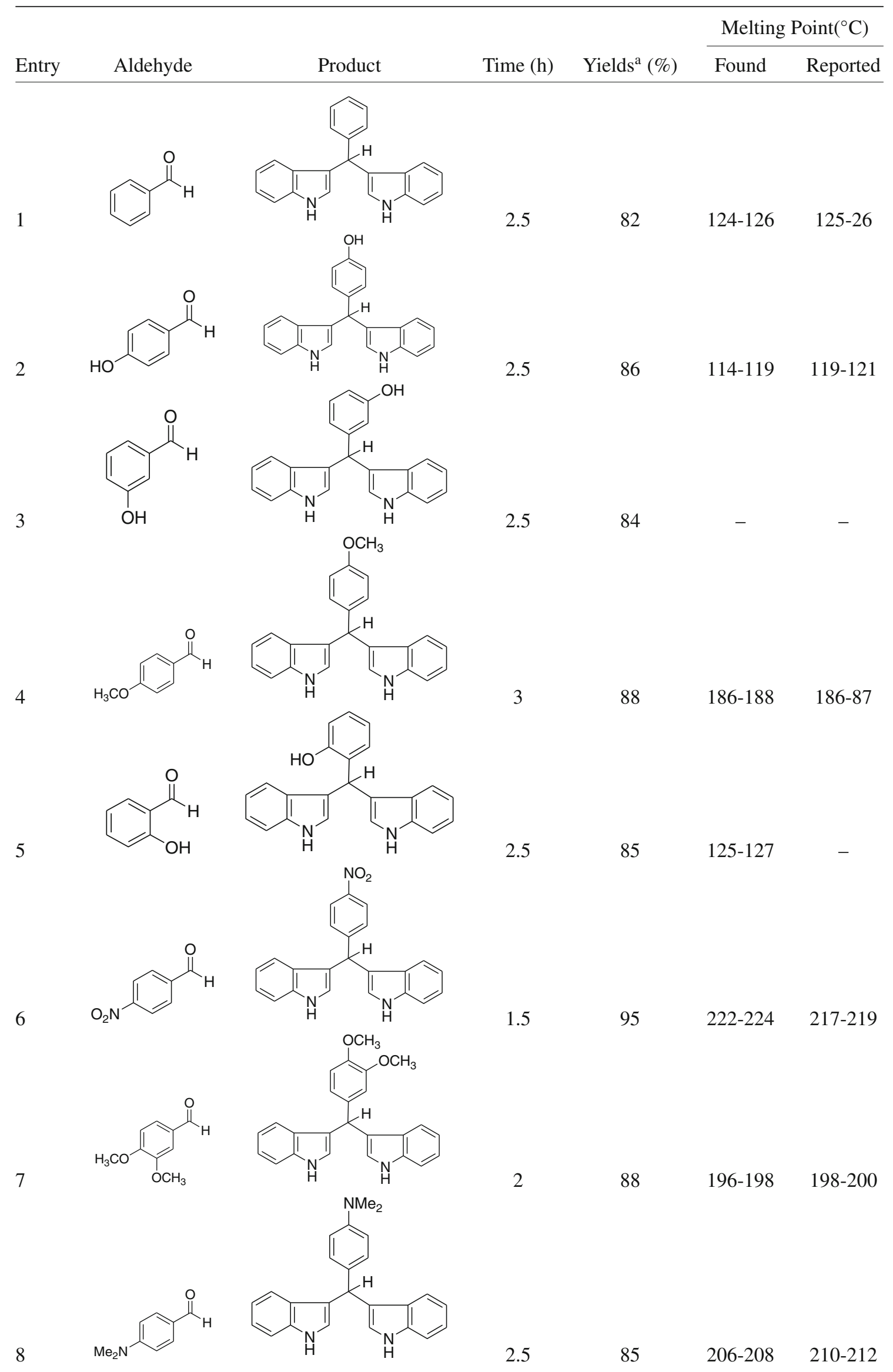


Table 3. (contd.)

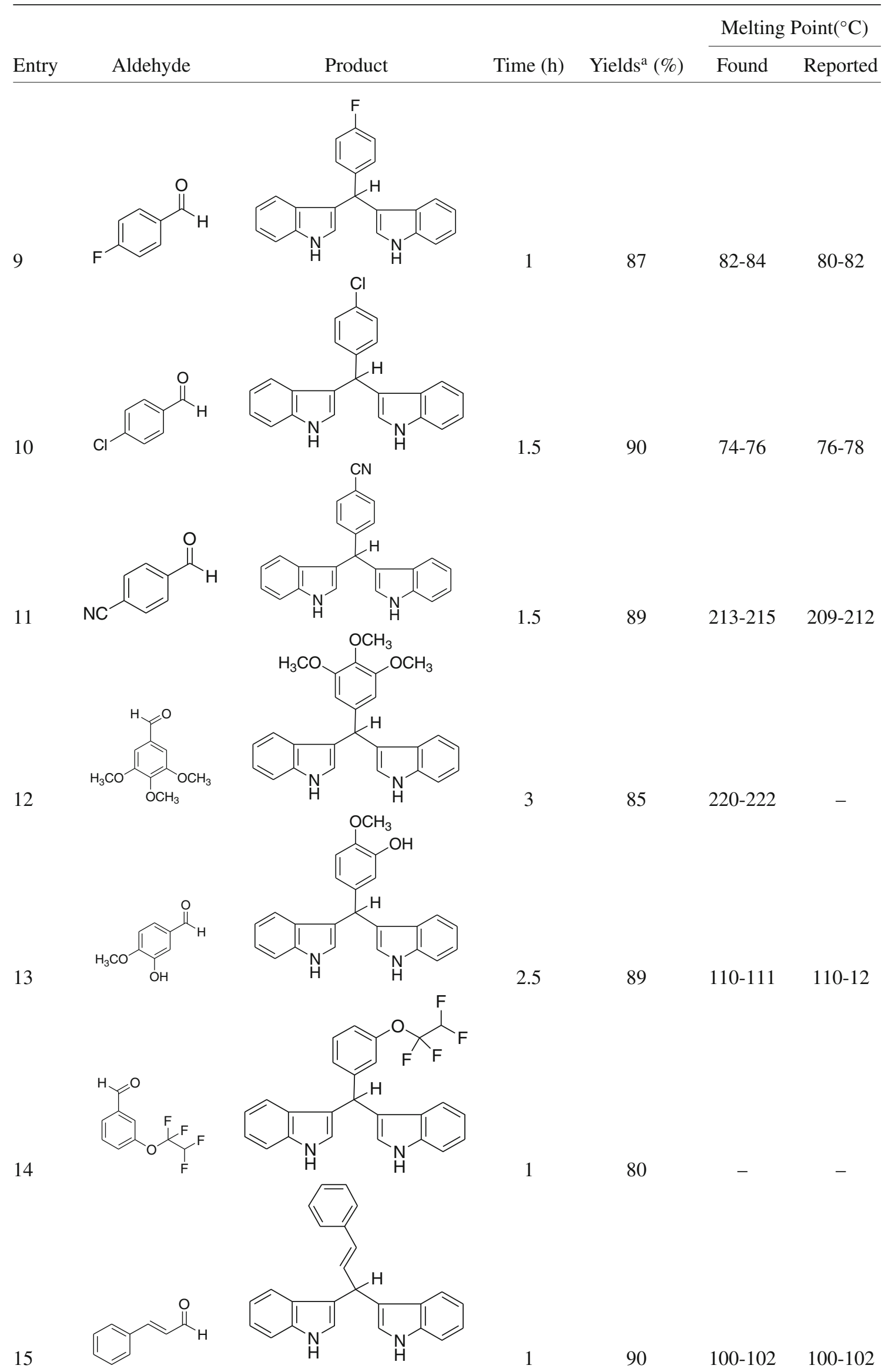


Table 3. (contd.)

Entry Aldehyde Time (h) Yields ${ }^{\mathrm{a}}(\%) \quad$ Found Reported

Reaction Conditions: Aldehyde (1 mmol), Indole $(0.117 \mathrm{~g}, 2 \mathrm{mmol})$, catalyst $(5 \mathrm{wt} \%)$; stirred in $5 \mathrm{~mL}$ acetonitrile at reflux temperature, time $1.5 \mathrm{~h}$. Isolated Yields.

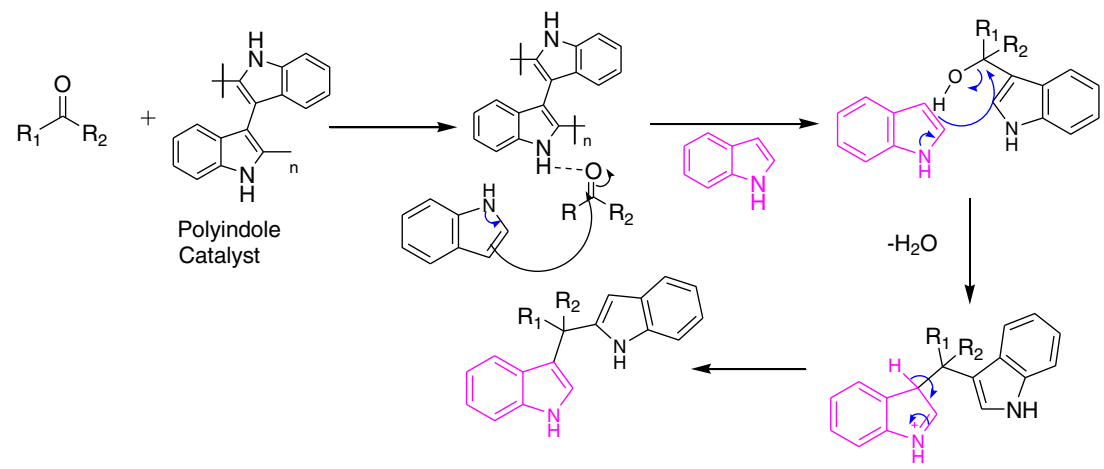

Scheme 2. Plausible mechanism for the synthesis of 3, 3'-arylmethylene bis-1H indole.

mole ratio was refluxed in acetonitrile $(5 \mathrm{~mL})$ with 5 wt $\%$ of catalyst for $1.5 \mathrm{~h}$ affording $95 \%$ yield of 3,3 'arylmethylene bis- $1 H$ Indole. In order to optimize the appropriate concentration of polyindole for the synthesis of 3, 3'-arylmethylene bis- $1 H$ Indole derivatives, the catalyst amount was varied from $0.5 \mathrm{wt} \%$ to $10 \mathrm{wt} \%$, the results of which are depicted in table 1 . With increase in catalyst amount, the yield of the reaction increased from $72 \%$ to $96 \%$, respectively. There was not much increase in the yield of product when 7.5 to $10 \mathrm{wt} \%$ of the catalyst was used. The reaction was also carried out with $\mathrm{CuCl}_{2}$ but the yield of the desired product was very low, less than $10 \%$ after prolonged reaction time. Based on these results, $5 \mathrm{wt} \%$ catalyst was used in further studies. The effect of various solvents on the yield of 3, 3'-arylmethylene bis- $1 H$ Indole was investigated and results are shown in table 2 . The reaction was complete in acetonitrile within $1.5 \mathrm{~h}$ with $5 \mathrm{wt} \%$ polyindole affording $95 \%$ yield of the desired product. However the reaction, was sluggish in benzene yielding $70 \%$ yield of 3,3'-arylmethylene bis- $1 H$ Indole. The extent of yield of 3, 3'-arylmethylene bis- $1 H$ Indole was in the order, $\mathrm{CH}_{3} \mathrm{CN}>\mathrm{EtOH}>\mathrm{THF}>\mathrm{DCM}>\mathrm{CHCl}_{3} \sim \mathrm{DMF}>1,4-$ dioxane $>$ benzene. This observation suggests that among the studied solvents, acetonitrile, being highly polar
Table 4. Reusability of polyindole.

\begin{tabular}{lcc}
\hline Entry & No. of cycle & Yield (\%) \\
\hline 1 & 1 & 95 \\
2 & 2 & 90 \\
3 & 3 & 85 \\
4 & 4 & 79 \\
5 & 5 & 75 \\
\hline
\end{tabular}

Reaction Conditions: Aldehyde (1 mmol), Indole $(0.117 \mathrm{~g}$, $2 \mathrm{mmol}$ ), catalyst ( $5 \mathrm{wt} \%$ ); stirred in $5 \mathrm{~mL}$ acetonitrile at reflux temperature, time $1.5 \mathrm{~h}$. Isolated Yields.

aprotic solvent enhances the activity of catalyst compared to other polar aprotic and non-polar solvents and gave the excellent yield in $1.5 \mathrm{~h}$ under reflux reaction condition. For further investigation we used $10 \mathrm{wt} \%$ catalyst and acetonitrile as a solvent.

To explore the further applicability and performance of this reaction, we extended the methodology for the synthesis of variety of 3, 3'-arylmethylene bis- $1 H$ Indole derivatives using a variety of aromatic aldehydes with indoles and substituted indoles. The results are summarized in table 3. Benzaldehyde and hydroxybenzaldehydes gave almost more than $85 \%$ yield 
Table 5. Comparison with other catalysts. Entry 9 is this work.

\begin{tabular}{|c|c|c|c|c|c|}
\hline Sr. No. & Catalyst $^{\mathrm{a}}$ & Solvent & $\operatorname{Temp}\left({ }^{\circ} \mathrm{C}\right)^{\mathrm{b}}$ & Time $(\mathrm{h})^{\mathrm{c}}$ & Yield $(\%)^{\mathrm{d}}$ \\
\hline 1 & $\mathrm{InF}_{3} \cdot \mathrm{H}_{2} \mathrm{O}$ & Aqueous & Room-Temp & $10-15$ & $94^{16}$ \\
\hline 2 & $\operatorname{Ln}(\text { OTf })_{3}$ & $\mathrm{EtOH} / \mathrm{H}_{2} \mathrm{O}$ & Room-Temp & 12 & $98^{8 \mathrm{~b}}$ \\
\hline 3 & $\mathrm{LiClO}_{4}$ & $\mathrm{CH}_{3} \mathrm{CN}$ & 100 & 5 & $90^{11}$ \\
\hline 4 & $\mathrm{ZrOCl}_{2} .8 \mathrm{H}_{2} \mathrm{O}$ & - & 50 & $3-12$ & $94^{8 a}$ \\
\hline 5 & {$[\mathrm{BMIM}] \mathrm{BF}_{4}$} & Solvent free & 100 & 4 & Trace $^{9}$ \\
\hline \multirow[t]{2}{*}{6} & Montmorillonite & & & & \\
\hline & K10 & Solvent free & Room -Temp & $1-6$ & $97^{23 a}$ \\
\hline 7 & $\mathrm{Sb}_{2}\left(\mathrm{SO}_{4}\right)_{3}$ & $\mathrm{MeOH}$ & Room -Temp & $1-3$ & $90^{24}$ \\
\hline 8 & Zeolite & $\mathrm{CH}_{2} \mathrm{Cl}_{2}$ & Room -Temp & 1 & $85^{25}$ \\
\hline 9 & Polyindole & $\mathrm{CH}_{3} \mathrm{CN}$ & 75 & $1-2$ & 95 \\
\hline
\end{tabular}

(table 3, entries 1, 2, 3, and 5). Di and trisubstituted methoxybenzaldehydes under similar reaction condition led to $\sim 82 \%$ yield of 3,3 '-arylmethylene bis$1 \mathrm{H}$ Indole (table 3, entry 7, 12 and 13) compared to mono substituted methoxybenzaldehyde (table 3 , entry 4) because of the electron donating ability of the methoxy group. Aldehydes possessing electronwithdrawing groups on the aromatic ring (table 3, entry 6,11 ) afforded 95 and $90 \%$ yield of the desired product. Halogenated and amino benzaldehydes gave around 80 to $90 \%$ yield (table 3, entry 8, 9, 10 and 14). It was observed that the reaction proceeds at a faster rate with all the aldehydes possessing electron-withdrawing substituent on the aromatic ring than aldehydes possessing electron-releasing substituent. Additionally, the methodology was further extended to unsaturated aldehydes and substituted indoles, affording almost $85 \%$ yields of 3, 3'-arylmethylene bis- $1 H$ Indole (table 3, Entry 15 and 16) without affecting the functionality in the indole ring which confirms the mild nature of polyindole.

The plausible mechanism for the synthesis of 3, 3'arylmethylene bis- $1 H$ indole is given in scheme 2 . The reaction proceeds through the activation of the carbonyl group by the polyindole catalyst through $-\mathrm{NH}$ bond, which makes the carbonyl carbon more electrophilic and induces the condensation with a second molecule of indole to give 3,3 '-arylmethylene bis- $1 H$ Indole with the recovery of polyindole catalyst.

\subsection{Reusability of catalyst}

In order to study the reusability of polyindole catalyst and thus make the process economical, the reaction of 4-nitrobenzaldehyde with indole was studied for a desired time under reflux reaction condition. Polyindole catalyst was recovered, filtered and washed with water repeatedly followed by ethanol and then dried in an oven at $65-70^{\circ} \mathrm{C}$ for half an hour. It was reused under optimized reaction conditions and was found that yield of 3, 3'-arylmethylene bis- $1 H$ Indole was almost comparable up to two runs without any significant loss of activity. The reusability of the catalyst was checked for four cycles and the corresponding yields obtained in each cycle are summarized in table 4 . The lower activity of the polyindole catalyst after third cycle was due to loss of some catalyst during washing and drying. The detailed comparison of the present protocol and various other methodologies is depicted in table 5 .

\section{Conclusions}

A simple methodology for an efficient synthesis of biologically active 3, 3'-arylmethylene bis- $1 H$ indoles using polyindole as a heterogeneous catalyst has been reported. The present protocol offers several advantages like short reaction time, high yield of the desired products, reusability of the catalyst, simple workup procedure and minimal use of toxic and hazardous chemicals compared to the traditional methods of synthesis.

\section{Supplementary Information (SI)}

Additional information related to characterization of the catalyst and synthesized compounds (XRD, SEM, FTIR, ${ }^{1} \mathrm{HNMR}$ and ${ }^{13} \mathrm{CNMR}$ ) are given in the supporting information and are available at http://www.ias.ac.in/ Journals/Journal_of_Chemical_Sciences.

\section{Acknowledgements}

Authors sincerely acknowledge ISRO, University of Pune for financial assistance. We also thank Centre for Materials for Electronic technology (C-MET) and Haribhai V. Desai College for characterization and Nowrosjee Wadia College, Pune for providing lab facilities. 


\section{References}

1. (a) Sundberg R J 1970 In The Chemistry of Indoles (Academic Press: New York); (b) Sundberg R J 1996 In Indoles Vol.18 (Academic Press: London)

2. Sivaprasad G, Perumal P T, Prabavathy V R and Mathivanan N 2006 Bioorg. Med. Chem. Lett. 16 6302

3. Bell R, Carmeli S and Sar N 1994 J. Nat. Prod. 571587

4. McDougal A, Gupta M S, Morrow D, Ramamoorthy K, Lee J E and Safe S H 2001 Breast Cancer Res. Treat. 66147

5. Safe S, Papineni S and Chintharlapalli S 2008 Cancer Lett. 269326

6. Maciejewska D, Szpakowska I, Wolska I, Niemyjska M, Mascini M and Maj-Zurawska M 2006 Bioelectrochemistry 691

7. Xia M, Wang S B and Yuan W B 2004 Synth. Commun. 343175

8. Chen D, Yu L and Wang P G 1996 Tetrahedron Lett. 37 4467

9. Kurosh R M and Masoumeh S-K 2009 Tetrahedron 65 8816

10. Firouzabadi H I, Jafarpoor M and Gadheri A $2006 \mathrm{~J}$. Mol. Catal. A: Chem. 253249

11. Ramesh C, Banerjee J, Pal R and Das B 2003 Adv. Synth. Catal. 345557

12. Ji S J, Zhou M F, Gu D G, Jiang Z Q and Loh T P 2004 Eur. J. Org. Chem. 71584
13. Yadav J S, Reddy B V S, Murthy C V S R, Kumar G M and Madan C 2001 Synthesis 5783

14. Meshram G A and Patil V D 2009 Synth. Commun. 4029

15. Yadav J S, Reddy B V S and Sunita S 2003 Adv. Synth. Catal. 345349

16. Nagarajan R and Perumal P T 2004 Chem. Lett. 33(2) 88

17. Mi X L, Luo S J, He J and Cheng P 2004 Tetrahedron Lett. 454567

18. Bandgar B P and Shaikh K A 2003 Tetrahedron. Lett. 44 1959

19. Koshima H and Matsuaka W 2002 J. Heterocyclic Chem. 391089

20. (a) Karthik M, Tripathi A K, Gupta N M, Palanichamy M and Murugesan V 2004 Catal. Commun. 5 371; (b) Reddy A V, Ravinder R, Reddy V L N, Goud T V, Ravikanth V and Venkateseswarlu Y 2003 Synth. Commun. 33 687; (c) Srinivasa A, Varma P, Hulikal V J and Mahadevan K M 2008 Monatsch. Chem. 139111

21. Feng X L, Guan C J and Zhao C X 2004 Synth. Commun. 34487

22. Zolfigol M A, Salehi P and Shirl M 2004 Phosphorus, Sulfur Silicon Relat. Elem. 1792273

23. Penieres-Carrillo G, Garcia-Estrada J G, GutierrezRamirez J L and Alvarez-Toledano C 2003 Green Chem. 533

24. Reddy A V, Ravinder K, Reddy V L N, Ravikanth V and Venkateswarlu Y 2003 Synth. Commun. 333687 